УДК 94(5) 323(519.3)-(519.5)

DOI: $10.18101 / 1994-0866-2019-4-71-77$

\title{
ЮЖНОКОРЕЙСКИЙ ЛИБЕРАЛИЗМ И ТРАДИЦИОННЫЕ КОНФУЦИАНСКИЕ ЦЕННОСТИ
}

\author{
(C) Хамутаева Саяна Владимировна \\ кандидат исторических наук, \\ Бурятский государственный университет имени Доржи Банзарова \\ Россия, 670000, г. Улан-Удэ, ул. Смолина, 24а \\ E-mail:khamutaeva@yandex.ru
}

Статья посвящена анализу взаимоотношений либерализма и традиционной конфуцианской этической мысли в Республике Корея (далее РК). В работе прослежен сложный эволюционный путь инкорпорации либерализма в условиях традиционалистскоконфуцианского общества РК. Автор приходит к выводу, что либерализм за десятилетия южнокорейской государственной самостоятельности вполне в ней адаптировался и пустил глубокие корни. Ныне либерализм здесь реально и на конституционной основе ограничивает сферу влияния государства и его институтов на человека, защищая права и свободы человека. Автор пытается выявить и объяснить причины этой довольно эффективной либерализации в РК, что представляется весьма важным в наше время.

Ключевые слова: либерализм; Республика Корея; Южная Корея; этическая мысль; конфуцианские ценности; конфуцианство.

\section{Для цитирования}

Хамутаева С. В. Южнокорейский либерализм и традиционные конфуцианские ценности // Вестник Бурятского государственного университета. Философия. 2019. Вып. 4. С. 71-77.

Либерализм как важнейшая политическая концепция и система взглядов столкнулся с мощнейшим контрнаступлением консерватизма, со всеми его разновидностями. Сегодня либерализм подвергается всеохватной - со всех политических институтов и групп - критике, от социалистов до ультра-националистов, монархистов и прочих страт «традиционных консерваторов». Соответственно, актуализируется огромной научно-гуманитарной важности задача ответить на эти социальные вызовы времени, определить новые пути трансформации либерализма (или адаптации к новым условиям, как в 1930-х осуществил Рузвельт).

Вызов первый. Отсутствует четкая и предельно простая, «народная» концепция либерализма - для широких масс населения, не только для «прослойки интеллигенции» (не только России и в большинстве стран третьего мира, но и в евроатлантических), весьма туманно-расплывчатое понимание ими долгого и сложного пути борьбы для достижения либерализма, отсюда нет осознания массами народа во всем мире фундаментальной ценности либерализма. Можно согласиться с распространенным мнением, что нынешнее поколение, не зная и не неся ответственности перед прошлыми поколениями, боровшимися и даже воевавшими за права, свободы и экономическое благоденствие - их и потомков, беззаботно пользуется настоящим и проедает базис будущего.

Проблема эта не только в отсутствии понятного, универсального определения, не только в отсутствии конструктивного общественного и/или научного дискурса 
или риторики, но в том, что либерализм и все однокоренные с ним слова преподносятся зачастую с негативным подтекстом, подвергаясь (нарочитой или добросовестно ошибочной) обструкции, интерпретируются как вседозволенность, распущенность, аморальность. Кроме того, известны примеры, когда либеральными лозунгами прикрывались далеко не либеральные действия, дискредитируя, таким образом, либерализм в целом.

Вызов второй. Сегодня назрела необходимость концептуальных перемен, как в теории, так и в практике либерализма. Сегодня многие исследователи приходят к выводу, что либерализм должен измениться, «измениться именно для того, чтобы не изменять себе, остаться политической философией свободы и освобождения» $[1$, с. 15]. Так, становятся популярны идеи о необходимости построения неких этических принципов, которые выступали бы как границы, ограничивающие либерализм, но делающие его более привлекательным в странах, где традиционные нормы социума далеки от теории и практики либерализма. Безусловно, при таком раскладе либерализм не меняет своих сущностных характеристик, но обзаводится внешними рамками, вызывающими более чувственное принятие либерализма в традиционных обществах.

Вероятно, этот процесс уже идет. На наш взгляд, эволюция самого либерализма неизбежна, ибо она заложена в его исходном коде, вере в возможность совершенствования всего и вся: либерализм Запада изначально постулировал отказ от неконкурентоспособных форм бытия, демонстрируя вечный поиск новых, технологичных прорывов во всех областях жизни людей. Либерализм, корнями уходя к идеям англо-саксонского рационализма и французского Просвещения, вовсе не стоял и не стоит на месте, так же вбирает в себя и аккумулирует достижения обществ Востока, в частности конфуцианской цивилизации.

В целом, подчеркнем, для либерализма, а вместе с ним и капитализма как безусловного детища или интеллектуального достижения коллективного ума Запада характерен рациональный подход. В то время как для Востока характерен, прежде всего, иррационализм, обусловленный более чувственным/интуитивным восприятием природы, мира, социума в лице семьи, старейшин рода, племени, тейпа, махалли, народа-нации. И конфуцианство, и другие восточные религии-культы (буддизм, джайнизм, индуизм, ислам, языческие культы) продуцируют незыблемость своих правил-догм, неразделенность человека и природы, неразделенность человека (а не личности) и этногруппы-уммы и т. п. институтов «родного» социума. Либерал, т. е. «западный человек» капиталистического общества - иной: он индивидуалист, революционер, постоянно разрушающий устоявшиеся табу, нормы, правила, традиции. В этом контексте борьбы двух цивилизационных моделей поведения людей представляется весьма любопытным и полезным опыт адаптации либерализма в РК, принявшей (безоговорочно?) рациональный либерализм совершенно чужеродного, западного изготовления, но сохранившей при такой мощной инкорпорации (аккультурации?) также эмоциональное, вполне восточное, этическое наполнение, конфуцианское и традиционалистское по сути.

Республика Корея как новое самостоятельное образование сумела обеспечить постепенное принятие идей либерализма, без видимого - массового - отторжения народом. Таким образом, реальный южнокорейский либерализм, установившийся в еще одном восточном обществе, доказывает неантагонистичность восточной морали и рационализма как мотора либерализма/капитализма. 
Известный кореевед И. А. Толстокулаков видит, что в настоящее время государство в РК регулирует свои взаимоотношения с гражданами на основе либеральных норм [6, с. 64]. Действительно, главные принципы либерализма в его классическом понимании в целом воплощены в Южной Корее: верховенство права, уважение к частной собственности, уважение к свободе слова, выборность органов власти народа, концептуальная база конституционных ограничений роли и влияния государства. Заметим, эти либеральные базовые принципы реализованы с чисто корейскими особенностями, тем не менее главный вектор либерализации экономики и демократизации общества выбран, и принципы либерализма в целом в стране и обществе функционируют реально.

Здесь важно будет отметить тот факт, что в полной мере либерализм не реализовался нигде, даже в «очаге либерализма» - Великобритании. И хотя изначально классический либерализм «не имеет никакой иной цели, кроме как повышение материального благосостояния людей, и не касается их внутренних, духовных и метафизических потребностей» [5], тем не менее в Республике Корея он претерпевает изменения, пытается отвечать на требования непосредственно южнокорейского народа в сохранении духовных, по большей части конфуцианских, ценностей. Южнокорейский либерализм шагает в ногу с бурно текущим временем, чутко чувствуя требования времени и пространства, вызовы глобализации в этом уголке Азии.

Рассмотрим особенности морали или этической мысли в установившемся в южнокорейском обществе либерализме.

1. Стержневым принципом корейского либерализма, т. е. уже нормой морали, является верховенство права. Именно этот принцип консолидирует, объединяя южнокорейцев в убеждении о правильности исторического выбора пути либерализации. Сегодня Южная Корея удивляет мир громкими судебными процессами и реальными арестами президентов страны, демонстрируя миру, а главное — своему народу, что «закон писан и для самого президента». Законопослушание как один из принципов конфуцианской этики явилось одним из факторов успешного принятия идеи верховенства права.

2. Уважение к частной собственности. Важнейшим условием развития демократии и капитализма является уважение частной собственности и принцип ее неприкосновенности. Данный принцип либерализма защищен Конституцией РК и внешне не отличается от стандартных западных формулировок этого принципа либерализма. Отметим, этот принцип был крайне хорошо воспринят трудолюбивыми южнокорейцами. Уважение к частной собственности как основа рыночной экономики воспринималось по народному принципу «как поработаешь, так и полопаешь». Так, этот принцип либерализма адаптируется в общество Южной Кореи через традиционные корейские ценности, такие как трудолюбие и бережливость.

3. Уважение к свободе слова. Нижеприведенная историческая справка о смене корейских режимов, демонстрирующая постепенное принятие, инкорпорацию либералистских принципов в общественную и государственную ткань Южной Кореи, также в частности показывает и эволюцию принципа уважения к свободе слова. С момента образования РК и к настоящему моменту этот принцип эволюционировал со статуса «де-юре» до статуса «де-факто». Южнокорейский народ добился этого принципа либерализма многочисленными акциями тяжелой борьбы: митингами и демонстрациями, которые, кстати, и до сегодняшнего дня не утихают перед 
голубым домом. Данный принцип укладывается в традиционные конфуцианские ценности - патриотизм (национализм), коллективизм и социальная ответственность. Чувство ответственности обычного человека, его любовь к родине, ответственность за коллектив, за родную провинцию и деревню заставляют его выходить на демонстрацию (т. е. защиту своих прав) и поныне.

4. Выборность власти - хребет либерализма, который также стремится найти опору в виде таких конфуцианских ценностей, как социальная ответственность и патриотизм. Южнокорейский народ демонстрирует весьма высокий процент явки на различного рода выборы, активная часть населения в большинстве своем относительно молодое поколение.

5. Концепции конституционных ограничений государства. Как справедливо отметила Е. В. Клименко, либерализм ограничивает сферу своего влияния на человека, изначально не стремится контролировать находящиеся вне сферы его компетенции вопросы духовной жизни [2, с. 14]. Единственное, что четко ограничивает либерализм - сферу влияния на человека со стороны общества и государства [2, с. 14]. Недопустим диктат как государства, так и общества. В РК либерализм реально и на конституционной основе ограничивает сферу влияния государства и его институтов на человека, защищая права и свободы человека. Именно постепенное принятие южнокорейским обществом первых четырех (вышеуказанных) принципов либерализма привело к постепенному принятию и идеи конституционного ограничения государства. Несмотря на то, что в Корее традиционно сильны идеи коллективизма, а интересы государства всегда выше интересов отдельного человека, в РК действительно работают концепции конституционных ограничений государства.

Либерализм в РК, в целом не конфронтируя с традиционными моральными конфуцианскими устоями общества, оптимально адаптирует их к современным реалиям, считая при этом, что конфуцианские ценности вполне коррелируются и даже полезны и стране и обществу.

История РК (история смены президентов, история «южнокорейских республик») показывает весь тернистый путь от восточного (пиетизма власти: придание ей особой значимости) мировоззрения масс и авторитаризма власти к реальному народоправству; она проявляет болезненную трансформацию коллективистского, догматизированного, клишированного сознания всего южнокорейского народа в сторону необходимости уважения прав и свобод человека, верховенства права, для их практической реализации и институциализации.

Приведем историческую справку развития РК, показывающую путь демократизации и либерализации. Раздел Кореи - не только следствие холодной войны, но и ее причина: идеологическое разделение в самом корейском народе, когда южнокорейцы избрали путь демократии и капитализма, переняли в теории правовую систему США, а северяне выбрали «исторический путь коммунизма». Южнокорейцы продемонстрировали свою решимость уже в апреле 1960 г. Так, президентство Ли Сынмана завершилось в результате знаменитой «апрельской революции», президент был вынужден покинуть страну навсегда. Южнокорейский народ не стал терпеть репрессивную политику Ли Сынмана (шантаж, террор, подкуп, расправы с конкурентами под прикрытием ложных обвинений и даже изменение Конституции) [3], и в конечном счете локальные демонстрации переросли в масштаб- 
ную революцию. Так, народ сам ввел выборность органов власти, парламент, конституционный суд; это был первый шаг от отказа от пиетета власти к переходу на первую ступень либерализации. Это была первая победа все еще традиционалистского общества над своими вековыми догмами.

1 октября 1960 г. началась Вторая Республика, премьер-министром утвержден (парламентом) Чан Мён. Это следующий шаг вперед, к освобождению от традиционного страха, когда народ РК сам решал свою судьбу, когда впервые стало ненаказуемо открытое обсуждение выбора дальнейшего пути развития, когда выдвигались и бурно дискутировались в народе разные точки зрения, даже вплоть до открыто социалистических и коммунистических взглядов...

Период президентства «отца корейского чуда» Пак Чонхи, в силу личных качеств ставшего диктатором и потому убитого своим народом, также есть этап политического взросления народа, освоения им азов «европейского» либерализма, осознания, что демократия и либерализм требуют защиты от диктатуры, как бы они ни были успешны в плане экономического развития. Как выявил А. Н. Ланьков, «все "диктатуры развития" имели одну особенность: экономический успех неизбежно подрывал их политическую базу. С ростом благосостояния рос образовательный уровень и формировался средний класс - а за этим неизбежно следовали политические перемены» [4]. А значит, «росла уверенность в собственных силах, и диктатура уже не казалась неизбежным злом» [4]. Кореевед И. А. Толстокулаков подчеркивает, что Пак Чонхи «признавал либерализм "гибельным для страны"», «отвергал принципы парламентской и либеральной демократии», более того, «разработал теорию «кореизированной» или «восточной» демократии» $[7$, c. 62].

Средний класс с университетским образованием, а главное, студенты, получающее университетское образование (благодаря Пак Чонхи), стали той основой, которые развернули движение за демократию в начале 1980 г., ставшее известным как «сеульская весна». А. Н. Ланьков указывает, что «в грандиозной демонстрации на площади перед сеульским вокзалом участвовало более 100 тысяч человек» [4].

Либерализация в Южной Корее проходит постепенный эволюционный путь. Приход к власти очередного генерала Ро Дэу тому доказательство. Либерализация вышла на новый уровень, уличные демонстрации толп уходят в прошлое, борьба за права идет чисто политическим путем: новые политические партии, деятельность реальных профсоюзов, расследуются факты попрания прав и свобод, выросла значимость Конституции. В 1991 г. проведены выборы в местные законодательные органы [3].

Ким Ёнсам - первый демократический президент Южной Кореи, именно в его период начала широко проводиться реальная либерализация общественно-политической и экономической жизни страны. Ким Ёнсам инициировал расследование в отношении бывших президентов Чон Духвана и Ро Дэу. Наконец, при Ким Ёнсаме верховенство права из декларации превращается в норму для южнокорейского общества и даже его властей.

Президент Ким Дэчжун поднял значение права на новый уровень - до уровня права всего корейского народа на воссоединение. Так, в Пхеньяне 13-15 июня 2000 г. состоялась историческая встреча между руководителем КНДР Ким Чениром и президентом РК Ким Дэчжуном, а их «Совместная декларация Юга и Севера» стала первым реальным сдвигом в деле объединения корейского народа. 
Он получил признание в мире: Нобелевскую премию мира за деятельность в защиту демократии и прав человека в Южной Корее и в Восточной Азии, а также на благо мира и согласия с Северной Кореей.

После обвинений в коррупции Но Мухён был первым президентом страны, которому парламент вынес импичмент, хотя и впоследствии отменен. В целом этот импичмент можно оценить как показатель изменения сознания южнокорейского общества в сторону чисто правовой процедуры отстранения от должности. Уже не будучи президентом страны, Ли Мёнбак в октябре 2018 г. также по обвинению в коррупции был приговорен к тюремному сроку на 15 лет и штрафу. По обвинению в коррупции и злоупотреблении властью следующий «слуга народа» Пак Кынхе была арестована, приговорена к 25 годам тюрьмы и штрафу. Эти наказания президентов демонстрируют верховенство права в РК, «которое не снилось даже многим европейским демократиям».

Верховенство права, закрепленное в Конституции, которое реализуется сейчас в Южной Корее, - не набор непонятных флуктуаций, а результат, прежде всего, постепенного изменения сознания, формирования понимания уважения прав и свобод человека. Принцип верховенства права сформирован снизу, эволюционным путем.

Сегодня мы видим, как южнокорейское общество, где традиционно сильны конфуцианские ценности - коллективизм, корпоративизм, клановость - пытается активно бороться с мировым злом: коррупцией, являющейся побочным следствием традиционных же ценностей, и делает это успешно через нормы права. Интересно, конфуцианской культуре свойственна идея сильной государственной власти, сильного лидера, но идеи либерализма и демократии, а именно принцип верховенства права, поставили закон выше лидера, выше всякого президента именно в конфуцианской Корее.

Для Южной Кореи характерна также явная патриархальность с низким социальным статусом женщины, но принцип прав человека, прав женщины, получив развитие именно в РК, и привел в конечном итоге к ситуации, когда президентом впервые в истории страны стала женщина - Пак Кынхе. Ради торжества идеи прав и свобод, принципа верховенства права южнокорейцы готовы отказаться от тормозящих развитие, уже изживающихся себя традиционных ценностей, таких как обычная восточная клановость с ее неизменной спутницей - коррумпированностью, бесправие и ущемление прав женщин, авторитаризм. Отметим, что принцип верховенства права опирается здесь на другую конфуцианскую ценность законопослушание. Традиционное законопослушание стало тем основанием, которое помогает адаптироваться принципу верховенства права в РК. Конституция и законопослушание стали базой верховенства права, принципа всеобщего равенства перед законом. Но также и социальная ответственность, патриотизм, готовность к самопожертвованию, самодисциплина - все эти конфуцианские ценности также сыграли свою позитивную, а не негативную (!) роль в инкорпорировании принципов либерализма в южнокорейское общество.

Таким образом, либерализм за десятилетия южнокорейской самостоятельности вполне в ней адаптировался и пустил глубокие корни. Обобщим возможные причины столь эффективной либерализации страны. Первая причина - в самих южнокорейцах, в их добровольном выборе своего пути - либерализации, пусть с подачи другого государства. Вторая причина - психологическое желание и/или 
открытость самих корейцев к достижениям человечества, готовность воспринимать и слушать, в то время как другие часто «в штыки» воспринимают многие действительно рациональные достижения иных культур, абсолютизируя «свои ценности»; в то же время южнокорейцы учитывают и возможность отказаться от своего, что уже тормозит развитие, что уже изжито. Третья причина - не механический внезапный тотальный перенос идей либерализма, а постепенный, эволюционный, адаптируемый «шаг за шагом». Либерализм в Республике Корея, повторим как главный урок, не конфронтируя с традиционными моральными конфуцианскими устоями общества, оптимально адаптирует их к современным реалиям, считая при этом, что конфуцианские ценности вполне коррелируются и даже полезны стране и южнокорейскому обществу.

\title{
Лuтература
}

1. Капустин Б. Г. Три рассуждения о либерализме и либерализмах // Полис. Политические исследования. 1994. № 3. С. 13-26.

2. Клименко Е. В. Концепция свободы: от Просвещения к либерализму // Вестник СПбГУКИ. 2014. № 2(19) июнь. С. 11-18.

3. Курбанов С. О. Курс лекций по истории Кореи: с древности до конца ХХ в. СПб.: Изд-во С.-Петерб. ун-та, 2002. 626 с.

4. Ланьков А. Н. Взлет и падение «диктатуры развития» в Южной Корее [Электронный ресурс] // Отечественные записки. 2013. Вып. № 6(57). URL: http://www.stranaoz.ru/2013/6/vzlet-i-padenie-diktatury-razvitiya-v-yuzhnoy-koree (дата обращения: 19.07.2019).

5. Мизес Л. Либерализм в классической традиции: пер. с англ. М.: Начала-Пресс, 1994.

6. Толстокулаков И. А. Развитие демократического процесса в Южной Корее в период VI Республики. Владивосток: Изд-во Дальневост. ун-та, 2003. 444 с.

7. Толстокулаков И. А. Политическая модернизация в Республике Корея (19451987 гг.) // Вестник ДВО РАН. 2005. № 2. С. 49-64.

\section{SOUTH KOREAN LIBERALISM AND TRADITIONAL CONFUCIAN VALUES}

\author{
Sayana V. Khamutaeva \\ Cand. Sci. (History), \\ Dorzhi Banzarov Buryat State University \\ 24a Smolina St., Ulan-Ude 670000, Russia \\ E-mail:khamutaeva@yandex.ru
}

The article analyzes the correlation of liberalism and traditional Confucian ethical thought in South Korea. We have traced a rocky road of incorporating liberalism into the traditionalist society of the Republic of Korea, and come to the conclusion that over the decades of South Korean independence liberalism completely adapted and took foothold in it. Now, liberalism in deed limits the sphere of influence of the state and its institutions on a person, protecting human rights and freedoms on the basis of constitutional grounds. The article makes an attempt to identify and explain the reasons for such an effective liberalization in the Republic of Korea.

Keywords: liberalism; the Republic of Korea; South Korea; ethical thought; Confucian values; Confucianism. 